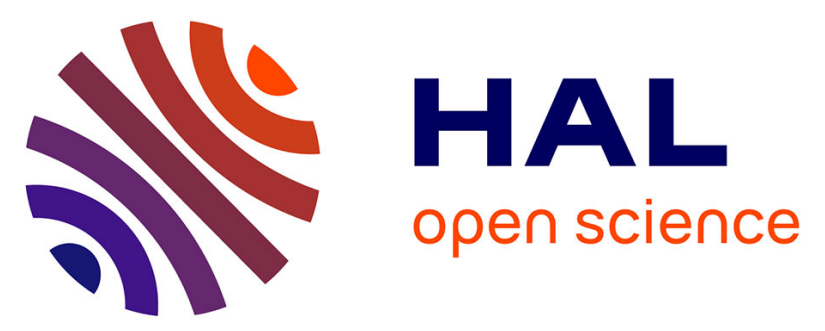

\title{
Effect of shortened photoperiod on the annual blood levels of GTH1 and GTH2 in rainbow trout (Oncorhynchus mykiss)
}

\author{
F. Le Menn, E. Bon, Marina Govoroun, Bernard Breton
}

\section{- To cite this version:}

F. Le Menn, E. Bon, Marina Govoroun, Bernard Breton. Effect of shortened photoperiod on the annual blood levels of GTH1 and GTH2 in rainbow trout (Oncorhynchus mykiss). 10. Conference of European Comparative Endocrinologists from Molecular to Ingrative Biology, Sep 1996, Rouen, France. Masson, Annales d'Endocrinologie, 57 (4) Supplément, 1996. hal-02770361

\section{HAL Id: hal-02770361 https://hal.inrae.fr/hal-02770361}

Submitted on 4 Jun 2020

HAL is a multi-disciplinary open access archive for the deposit and dissemination of scientific research documents, whether they are published or not. The documents may come from teaching and research institutions in France or abroad, or from public or private research centers.
L'archive ouverte pluridisciplinaire $\mathbf{H A L}$, est destinée au dépôt et à la diffusion de documents scientifiques de niveau recherche, publiés ou non, émanant des établissements d'enseignement et de recherche français ou étrangers, des laboratoires publics ou privés. 


\title{
18th Conference of \\ European Comparative Endocrinologists from Molecular to Integrative Biology
}

\author{
September 10th-14th, 1996 \\ Palais des Congrès \\ Rouen - France \\ ABSTRACTS OF LECTURES \\ AND COMMUNICATIONS
}

\section{European Society for Comparative Endocrinology Council}

President:

Vice-President :

Secretary-Treasurer:

Honorary Vice-President :

Members:

\author{
A. De Loof, Belgium \\ $H$. Vaudry, France \\ E.W. Roubos, The Netherlands \\ F. Gracia-Navarro, Spain \\ $X$. Bellès, Spain ; D. Larhammar, Sweden ; \\ G.M. Coast, United Kingdom ; R. Pierantoni, Italy ; \\ S. Dufour, France ; A.M. Polzonetti-Magni, Italy ; \\ W.P.M. Geraerts, The Netherlands; \\ F. Sehnal, Czech Republic; J. Koolman, Germany
}

Local Organizing Committee

Chairman:

H. Vaudry

Members:
V. Carpentier, L. Cazin, N. Chartrel, V. Contesse, J.M. Danger,

C. Delarue, L. Desrues, M. Feuilloley, S. Jégou,

M.K. Kodjo, M. Lamacz, F. Leboulenger, I. Lihrmann,

E. Louiset, A.G. Mensah-Nyagan, M. Montéro, I. Remy-Jouet, M.C. Tonon, H. Tostivint, L. Yon 
stimulatory effect on GTH-II release that increases with testicular development and sex steroid production in catfish. Pituitary responsiveness to GABA was partially correlated with sGnRHa action suggesting that the stimulatory effect of GABA may be mediated by activation of the $\mathrm{GnRH}$ system. The lack of effect of sulpiride indicates that GABA action is independent of the inhibitory dopaminergic system in the male African catfish. Supported by the Wellcome Trust (UK).

\section{P215 DEVELOPMENT AND VALIDATION OF A RADIO- IMMUNOASSAY FOR STUDYING PLASMA LEV- ELS OF GONADOTROPIN II (GTH-II) IN STRIPED BASS (MORONE SAXATILIS) \\ O. Blaise, E. Mananos and Y. Zohar \\ Center of Marine Biotechnology, University of Maryland, 701 East Pratt Street, Baltimore, MD 21202, USA.}

Striped bass is a commercially important farmed fish and an emerging model for the study of reproductive endocrinology. An ELISA for striped bass (stb) GtH-II (Mananos et al., 1996) was found to be affected by plasma interference. Therefore, a radioimmunoassay (RIA) for stbGtH-II was developed and validated for plasma measurements. Intact GtH-II purified from pituitaries of hybrid striped bass (Morone saxatilis $\mathrm{x}$ Morone chrysops) was used for the labeled ligand and the standard, and the antibody was raised against $\beta$ subunit of this hormone (Mananos et al., 1996). The sensitivity of this assay was $0.4 \mathrm{ng} / \mathrm{ml}$. Serial dilution of striped bass plasma and of pituitary extracts of different Morone sp. were parallel to the standard curve. An stbGtH-II internal standard placed into plasma of immature fish (with no detectable levels of GtH-II) was measured faithfully. These results indicate no plasma interference in this assay. The RIA was used to study the in vivo effect of $\mathrm{GnRH}$ on $\mathrm{GtH}$-II release in striped bass. Injection of female striped bass and hybrid striped bass with [D-Ala ${ }^{6}$, Pro $^{9}$ $\mathrm{NEt}]-\mathrm{LHRH}(50 \mu \mathrm{g} / \mathrm{kg})$ induced a similar rapid increase in the circulating $\mathrm{GtH}$-II level, which was maintained for 24 hours. Female striped bass were injected with two doses of the three native forms of $\mathrm{GnRH}$ present in striped bass : seabream (sb) GnRH, salmon (s) GnRH and chicken (c) GnRH-II. All three forms induced a dose-dependent GtH-II secretion, with a potency order of cGnRH-II > sGnRH > sbGnRH. Therefore, the stbGtH-II RIA is an additional reliable tool for the study of hormonal control of reproduction in striped bass and other Morone species.

P216 EFFECT OF SHORTENED PHOTOPERIOD ON THE ANNUAL BLOOD LEVELS OF GTH1 AND GTH2 IN RAINBOW TROUT (ONCORHYNCHUS MYKISS)

F. Le Menn (1), E. Bon (2), M. Govorum (3) and B. Breton (3)

(1) Laboratoire de Biologie de la Reproduction des Poissons, Université Bordeaux I, av. des facultés, 33405 Talence Cedex, France; (2) Les Salmonidés d'Aquitaine, 40260 Castests, France; (3) Laboratoire de Physiologie des Poissons, INRA, University Rennes-Beaulieu, av. du General Leclerc, 35042 Rennes, France.

3 groups of a precocious winter strain of rainbow trout were reared at constant temperature $\left(8.5^{\circ} \mathrm{C}\right)$ in spring water on a spawner diet. Fish from group $\mathrm{N}$ were submitted to a simulated natural 12 month photoperiodic cycle for spawning in early winter. Fish from group S9 were submitted to a shortened photoperiodic cycle by reducing light hours/day, 2 months after spawning, from 16 to $8 \mathrm{~h}$ over 7 months, resulting in late summer spawning. Fish from group S6 were treated in the same way over 6 months, 2 weeks after spawning, resulting in late spring spawning. Twice a month samples were analysed for GTH1 and GTH2 using specific RIA.

$\mathrm{N}$ fish GTH1 profile exhibits 3 successive slight increases and decreases followed by a final sharp peak. The first, at daylight/12 hours, peaks one month before the very slow oocyte development phase (VSD). The second corresponds to the slow development (SD) and the third the rapid development (RD) phases. The last occurs during maturation, peaking at $30 \mathrm{ng} / \mathrm{ml}$. In S9 fish, the four increases in GTH1 persist but the first during the VSD phase. The second peak during the SD phase is almost doubled. In S6 fish only 2 peaks occur : one very high $(65 \mathrm{ng} / \mathrm{ml})$ during the vitellogenesis, the second during the final phase and the ovulation.

GTH2 profiles exhibit a unique peak during ovulation for each group. Hormone levels diminish along with the cycle length.
P217 DEVELOPMENT OF A HOMOLOGOUS RIA FOR GTH II OF THE MEDITERRANEAN YELLOWTAIL, SERIOLA DUMERILII

M.P. Garcia Hernandez (1), A. Garcia Ayala (1) B. Agulleiro (1), W. Van Dijk (2), R.W. Schulz (2)

(1) Dept. Cell Biology, Faculty of Biology, University of Murcia, 30100 Murcia, Spain; (2) Dept. of Experimental Zoology, University of Utrecht, $3584 \mathrm{CH}$ Utrecht, The Netherlands.

Highly purified $M$. yellowtail GTH II and its $\beta$-subunit were used to raise antisera in rabbit. Anti- $\alpha, \beta$ GTH II, but not anti- $\alpha, \beta$ GTH II, cross-reacted with TSH cells. Hence, the latter antiserum was used to set up a GTH II RIA system. The GTH II $\beta$-subunit was iodinated with $\left[{ }^{125} \mathrm{I}\right]$ using the chloramine T method. Intact GTH II was used to compete with the radiolabeled GTH II $\beta$-subunit for the antigen binding sites. At a final dilution of $1: 70,000$ the antiserum bound approximately $30 \%$ of the labeled $\beta$-subunit $(10,000 \mathrm{cpm})$. The sensitivity of the RIA was $0.25 \mathrm{ng}$ GTH II $\beta$-subunit $/ \mathrm{ml}$ and the standard curve ranged from 0.25 to $50 \mathrm{ng} / \mathrm{ml}$. To validate the assay, GTH II levels were measured in serum samples collected from adult fish that were sampled before and at different times after a single injection of salmon GnRH $(50 \mu \mathrm{g} / \mathrm{kg})$. A significant increase in the GTH II blood levels was recorded as compared to pre-injection levels in the sGnRH treated fish at $1,2,4$, and $8 \mathrm{~h}$ after injection, while control levels were attained $24 \mathrm{~h}$ after $\mathrm{sGnRH}$ injection. Moreover, serial dilutions of pituitary extracts led to a displacement of radiolabeled GTH II $\beta$-subunit that was parallel to the standard curve. We conclude that the assay system is suitable to quantify circulating and pituitary GTH II levels.

\section{P218 COMPARATIVE EFFECTS OF ACETYLCHOLINE ON $\alpha$-MSH RELEASE FROM FROG AND RAT PARS INTERMEDIA}

M. Garnier, M. Lamacz, L. Galas, M.C. Tonon and H. Vaudry

Europ. Inst. Pept. Res. (IFRMP $n^{\circ}$ 23), Lab. Cell. Mol. Neuroendocrinol., INSERM U413, UA CNRS, Univ. Rouen, 76821, Mt-St-Aignan, France.

The involvement of acetylcholine (ACh) in the control of melanotrope cell activity has been demonstrated in various species. In the present study, we have investigated the effect of muscarinic agonists on frog and rat pituitary melanotrophs. Muscarine caused a dose-dependent stimulation of $\alpha$-MSH release from perifused frog neurointermediate lobes (NIL), and this effect was mediated by $M_{1}$ muscarinic receptors. Muscarine provoked an increase of the intracellular calcium concentration $\left(\left[\mathrm{Ca}^{2+}\right]_{\mathrm{i}}\right)$ in cultured frog melanotrophs. The effect of muscarine was totally suppressed when $\mathrm{Ca}^{2+}$ was omitted in the incubation medium. However, the calcium channel blockers nifedipine $\left(10^{-5} \mathrm{M}\right)$ and $\omega$-conotoxine $\left(10^{-6} \mathrm{M}\right)$ did not affect the muscarine-induced $\alpha$-MSH secretion. Muscarine stimulated $\mathrm{IP}_{3}$ formation in frog NIL. Pretreatement of frog NIL with PMA $\left(10^{-6} \mathrm{M}, 24 \mathrm{~h}\right)$ markedly reduced the muscarine-induced $\alpha$-MSH secretion. The tyrosine kinase inhibitor ST $638\left(10^{-4} \mathrm{M}\right)$ also reduced the effect of muscarine on $\alpha$-MSH release and $\left[\mathrm{Ca}^{2+}\right]_{\mathrm{i}}$. In the rat NIL, ACh exerted an inhibitory effect on $\alpha$-MSH release. The action of $\mathrm{ACh}$ was mimicked by muscarine and blocked by atropine, but it was not suppressed by the $M_{1}$ muscarinic antagonist pirenzepine. Incubation of rat NIL with pertussis toxin suppressed the effect of muscarine on $\alpha$-MSH release. Besides, muscarine reduced the cAMP content of rat melanotrope cells. These data demonstrate that $\mathrm{ACh}$ controls the activity of pituitary melanotrophs in both frog and rat through activation of muscarinic receptors. However, the transduction pathways and the final responses in the two models are totally different. Supported by a Human Capital and Mobility network and the Conseil Regional de Haute-Normandie.

\section{P219 MORPHOLOGICAL CHANGES INDUCED BY BACKGROUND ADAPTATION IN THE FROG PARS INTERMEDIA*}

P. Gómez-Luna, J.L. González de Aguilar, A. Ruiz-Navarro, R. Vázquez-Martínez, M.C. Tonon (1), H. Vaudry (1), M.M. Malagón and F. Gracia-Navarro Department of Cell Biology, University of Córdoba, Spain. (1) E.I.P.R., Laboratory of Cellular and Molecular Neuro- 